\title{
PERANCANGAN FASILITAS PABRIK TAHU UNTUK MEMINIMALISASI MATERIAL HANDLING
}

\author{
MERRY SISKA DAN HENRIADI \\ Teknik Industri, Fakultas Sains dan Teknologi, UIN Sultan Syarif Kasim Riau, Pekanbaru \\ Laman: merrysiska@yahoo.com
}

\begin{abstract}
ABSTRAK
UD. Dhika Putra merupakan perusahaan yang bergerak dalam pembuatan tahu. Saat ini kondisi layout fasilitas produksi dan kondisi fisik lingkungan kerja di perusahaan mengalami kendala. Penelitian ini bertujuan untuk merancang ulang tata letak fasilitas pabrik pembuatan tahu yang dapat meminimalkan panjang lintasan material handling serta menerapkan metode $5 S$ untuk meningkatkan produktivitas kerja. Pendekatan yang digunakan pada perancangan ulang tata letak fasilitas pabrik adalah dengan menggunakan pendekatan Systematic Layout Planning (SLP) yang dapat dikategorikan ke dalam tiga tahapan, yaitu tahap analisis aliran material, tahap penelitian dan tahap proses seleksi. Sedangkan metode 5S terdiri dari beberapa tahapan untuk mengatur kondisi tempat kerja yang berdampak terhadap efektivitas kerja, efisiensi, produktivitas dan keselamatan kerja. Hasil penelitian ini menyimpulkan bahwa layout usulan yang terpilih untuk dijadikan layout akhir dalam penelitian ini menunjukkan penurunan panjang lintasan material handling yang cukup signifikan yaitu 45 m atau sekitar 19,2\% lebih pendek dari layout awal. Berkurangnya panjang aliran material handling layout yang terpilih juga dipengaruhi karena penataan lingkungan kerja dengan metode $5 \mathrm{~S}$.
\end{abstract}

Kata kunci: material handling, tata letak fasilitas pabrik, systematic layout planning, metode 5S

\begin{abstract}
UD. Dhika Putra is a tahu manufacturing company. Currently, the company is having some problems in production facility layout and physical environment. This study aimed to redesign the facility layout of tahu manufacturing company to minimize the path length of material handling and apply the 55 method to enhance work productivity. The approach used to redesign the plant facility layout is Systematic Layout Planning (SLP), which can be categorized in three stages, namely material flow analysis, research, and selection. While the 55 method consist of several steps to organize workplace condition that affect on the effectiveness, eficiency, productivity, and safety. This study concluded that the chosen layout for the final layout showed a significant decrease in path length of material handling, i.e 45 meters or about 19,2\%. The decreasing of material handling path length on the choosen layout was also influenced by the arrangement of the work place by using 55 method.
\end{abstract}

Key words: material handling, layout of plant facilities, Systematic layout planning, 5S Method

\section{PENDAHULUAN}

Hadiguna dan Setiawan (2008) mendefinisikan tata letak sebagai kumpulan unsur-unsur fisik yang diatur mengikuti aturan atau logika tertentu. Sistim material handling yang kurang sistimatis menjadi masalah yang cukup besar dan mengganggu kelancaran proses produksi sehingga mempengaruhi sistim secara keseluruhan. Menurut Wignjosoebroto (2009), tata letak yang baik adalah tata letak yang dapat menangani sistim material handling secara menyeluruh sedangkan Purnomo (2004) menyebutkan tata letak fasilitas yang dirancang dengan baik pada umumnya akan memberikan kontribusi yang positif dalam optimalisasi proses operasi perusahaan dan pada akhirnya akan menjaga kelangsungan hidup perusahaan serta keberhasilan perusahaan.
Tata letak pabrik ini meliputi perencanaan dan pengaturan letak mesin, peralatan, aliran bahan dan orang-orang yang bekerja pada masing-masing stasiun kerja. Jika disusun secara baik, maka operasi kerja menjadi lebih efektif dan efisien (Wignjosoebroto, 2009). Pada dasarnya tujuan utama perancangan tata letak adalah optimasi pengaturan fasilitas-fasilitas operasi sehingga nilai yang diciptakan oleh sistim produksi akan maksimal (Purnomo, 2004).

UD. Dhika Putra merupakan sebuah home industry yang bergerak dalam pembuatan tahu. UD. Dhika Putra berdiri sejak tahun 2003, terletak di Jalan Sukajadi, Desa Tarai Bangun Kubang Raya Kabupaten Kampar. Saat ini kondisi layout fasilitas produksi dan kondisi fisik lingkungan kerja di perusahaan mengalami kendala. Kondisi layout 
fasilitas produksi di perusahaan mengalami kendala dalam hal jarak pemindahan bahan baku (material handling) yang kurang efisien. Dimana dalam proses produksinya terdapat aliran pemindahan bahan yang berpotongan (cross movement) dikarenakan tata letak mesin yang kurang teratur sehingga dapat mengakibatkan proses produksi terganggu. Jarak antar departemen produksi yang cukup jauh menimbulkan ongkos material handling yang cukup besar. Selain itu hubungan kedekatan antar stasiun kerja kurang diperhatikan sehingga membuat aliran material handling menjadi kurang optimal. Belum tersedianya parkir dan area penimbunan bahan baku juga ikut menjadi kendala pada perusahaan ini, seperti terlihat pada Gambar 1. Melihat kondisi ini, perlu adanya suatu pertimbangan untuk mengubah tata letak fasilitas yang ada menjadi lebih efektif dan efisien.
Gambar 2 menunjukkan kondisi fisik lingkungan kerja yang kurang tertata rapi, seperti adanya percampuran antara wadah (ember) yang berisi tahu dan wadah yang tidak berisi tahu pada area gudang bahan jadi. Keadaan ini menunjukkan ketidakteraturan dalam penataan lingkungan kerja. Selain itu di pabrik tahu ini juga ditemui kondisi lantai dan peralatan kerja yang masih kotor serta belum adanya pemberian label dan batas yang jelas pada penempatan peralatan kerja. Kondisi lingkungan kerja tersebut memerlukan beberapa upaya perbaikan melalui penerapan program " $5 \mathrm{~S}$ ". Penelitian ini bertujuan merancang ulang tata letak fasilitas pabrik pembuatan tahu yang dapat meminimalkan panjang lintasan material handling serta menerapkan metode 5S untuk meningkatkan produktivitas kerja.

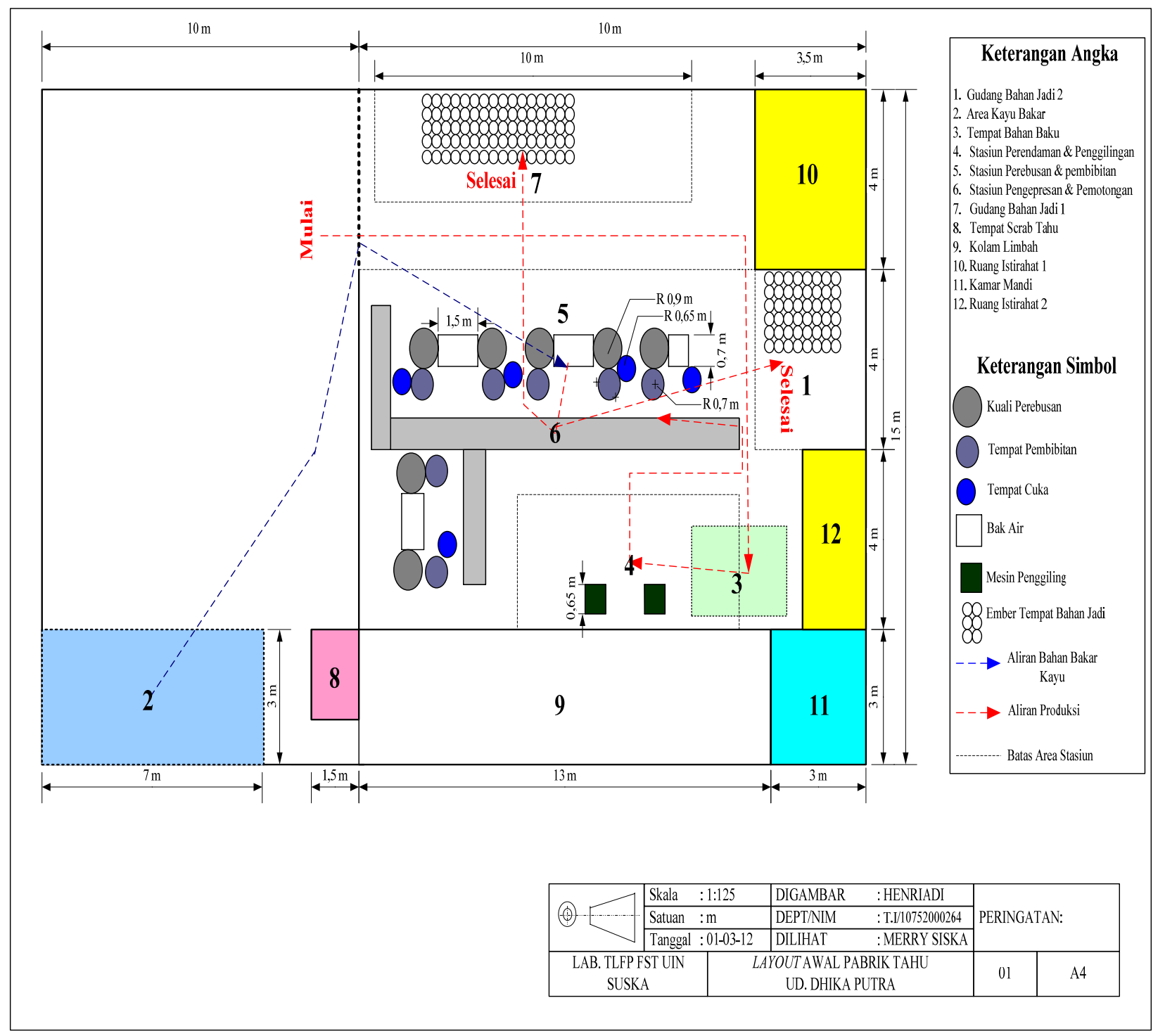

Gambar 1. Layout Awal Pabrik Pembuatan Tahu UD. Dhika Putra 

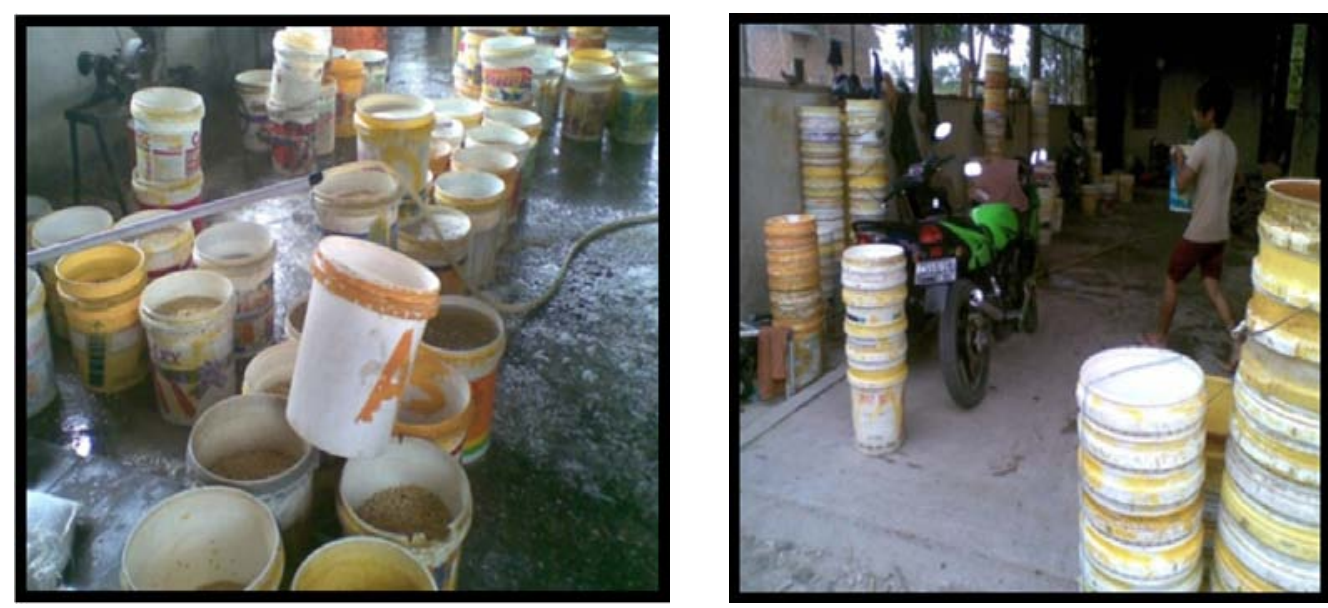

Gambar 2. Kondisi Fisik Lingkungan Kerja yang Tidak Rapi pada Pabrik Tahu UD. Dhika Putra

\section{METODE}

Langkah awal yang harus dilakukan sebelum melakukan penelitian adalah melakukan studi pendahuluan. Studi pendahuluan dilakukan ke Home Industri pembuatan tahu UD. Dhika Putra yang berada di jalan Sukajadi, Kubang Raya kota Pekanbaru yang menjadi objek penelitian. Langkah ini dilakukan untuk mengetahui permasalahan yang ada di pabrik pembuatan tahu ini.

Langkah selanjutnya yang dilakukan adalah pengumpulan data awal kondisi layout pabrik sesuai dengan pendekatan Systematic Layout Planning (SLP) yang dikembangkan oleh Richard Muther (Apple, 1990). Tahapan yang digunakan untuk perancangan tata letak fasilitas pabrik sesuai dengan pendekatan Systematic Layout Planning (SLP) menurut Purnomo (2004) terdiri dari tiga tahapan. Tahapan pertama adalah tahap analisis, mulai dari analisis aliran material, analisis aktivitas, diagram hubungan aktivitas, pertimbangan keperluan ruangan dan ruangan yang tersedia. Tahapan kedua adalah tahap penelitian, mulai dari perencanaan diagram hubungan ruangan sampai dengan perancangan alternatif tata letak. Sedangkan tahapan ketiga adalah proses seleksi dengan jalan mengevaluasi alternatif tata letak yang telah dirancang. Data-data yang diperlukan untuk perencanaan tata letak dengan menggunakan metode SLP yaitu data rancangan produk, rancangan proses dan rancangan jadwal produksi.

Perbaikan kondisi lingkungan kerja pada pabrik ini dapat dilakukan dengan menerapkan metode 5S. 5S adalah prinsip yang paling mudah dipahami, prinsip ini memungkinkan untuk memperoleh partisipasi secara total. Merujuk kepada pendapat seorang pakar bahwa tidak akan berhasil bila 5S tidak diterapkan, sebaliknya keuntungan yang diperoleh bila dengan menerapkan $5 \mathrm{~S}$ akan terlihat dengan jelas, diantaranya terciptanya keteraturan melalui manajemen lingkungan kerja yang baik. Menurut Linstiani (2010) penjabaran dari metode " $5 \mathrm{~S}$ " adalah sebagaimana berikut:

a. Seiri (Sisih/Ringkas)

Menyisihkan barang-barang yang tidak diperlukan di tempat kerja. Prinsip dalam menerapkan konsep yang pertama ini adalah mengidentifikasi dan menjauhkan barang yg tidak diperlukan di tempat kerja.

b. Seiton (Penataan)

Menata barang-barang yang diperlukan supaya mudah ditemukan oleh siapa saja bila diperlukan. Setiap barang mempunyai tempat yang pasti, jelas dan diletakkan pada tempatnya. Adapun metode yang dapat digunakan adalah pengelompokan barang, penyiapan tempat, memberi tanda batas, memberi tanda pengenal barang, membuat denah/ peta pelaksanaan barang

c. Seiso (Pembersihan)

Membersihkan tempat kerja dengan teratur sehingga tidak terdapat debu di lantai, mesin dan peralatan. Prinsip: bersihkan segala sesuatu yang ada di tempat kerja. Membersihkan berarti memeriksa dan menjaga.

d. Seiketsu (Pemantapan)

Memelihara taraf kepengurusan rumah tangga yang baik dan organisasi tempat kerja setiap saat. Prinsip: semua orang memperoleh informasi yang dibutuhkan dengan tepat waktu. Pertahankan lingkungan 3S (Sisih, Susun, Sasap) yang telah dicapai, cegah kemungkinan terulang kotor/ rusak.

e. Shitsuke (Pembiasaan)

Memberikan penyuluhan kepada semua orang agar mematuhi disiplin pengurusan rumah tangga yang baik atas kesadaran sendiri. Prinsip: berikan pengarahan kepada orang-orang untuk berdisiplin mengikuti cara dan aturan penanganan house 
keeping atas dasar kesadaran. Lakukan apa yg harus dilakukan dan jangan melakukan apa yang tidak boleh dilakukan.

Sedangkan tahapan pengolahan data untuk penerapan 5S menurut Osada (2004) adalah sebagai berikut:

1. Perancangan Metode 5S

Tahap ini merupakan tahap paling awal dari penerapan metode $5 \mathrm{~S}$, pada tahap ini dilakukan perancangan metode 5S. Maksud perancangan disini adalah lebih kepada perencanaan apa saja yang akan dilakukan nantinya pada tahap penerapan. Misalnya saja menentukan lokasi yang dianggap bermasalah, menentukan peralatan apa saja yang perlu diterapkan metode $5 \mathrm{~S}$ ini serta bagaimana cara untuk menanggulanginya.

2. Sosialisasi Metode $5 \mathrm{~S}$

Tahap sosialisasi ini adalah tahapan selanjutnya setelah perancangan dilakukan. Pada tahap ini melalui bantuan dari pimpinan perusahaan dilakukan sosialisasi kepada semua karyawan mengenai penerapan metode $5 \mathrm{~S}$ yang akan dilakukan. Semua karyawan diberikan penjelasan tentang pengertian, tujuan serta manfaat dari metode 5S. Selain itu juga diberikan sosialisasi tentang rancangan metode $5 \mathrm{~S}$ yang telah dibuat.

3. Penerapan Metode 5S

Tahapan ini merupakan proses penerapan yang akan dilakukan setelah dilakukan proses perancangan dan sosialisasi 5S. Tahapan ini dilakukan untuk merelisiasikan perancangan metode $5 \mathrm{~S}$ yang telah dibuat ada 5 aspek yang akan diterapkan yaitu seiri, seiton, seiso, seiketsu, dan shitsuke.

4. Evaluasi Penerapan Metode 5S

Pada tahap ini dilakukan proses evaluasi terhadap penerapan yang telah dilakukan.
Tahapan ini dilakukan bertujuan untuk mengetahui sejauh mana penerapan 5S yang telah dilakukan pada pabrik tahu UD. Dhika Putra. Dari evaluasi ini nantinya bisa diketahui apa saja yang telah diterapkan dan apa saja yang menjadi kendala pada penerapan metode ini dan pada tahap evaluasi ini juga dilakukan proses pengecekan kegiatan yang dilakukan dengan menggunakan tabel evaluasi kegiatan.

Setelah selesai tahapan-tahapan di atas maka langkah selanjutnya yang dilakukan adalah membuat layout akhir berdasarkan kombinasi antara alternatif tata letak terbaik dan perancangan metode $5 \mathrm{~S}$.

\section{HASIL DAN PEMBAHASAN}

\section{Perancangan Ulang Tata Letak Fasilitas Pabrik}

Perancangan ulang tata letak fasilitas pabrik dimulai dari hasil analisis aliran material berupa Peta Proses Operasi pada Gambar 3 kemudian dilakukan perhitungan jarak material handling layout awal seperti pada Tabel 1. Total kebutuhan area pabrik ini meliputi seluruh area kerja/departemen yang digunakan selama proses produksi, baik area kerja yang telah rancang ulang maupun area kerja yang memang telah disesuaikan dengan kondisi pabrik dari awal. Perhitungan selengkapnya dapat dilihat pada Tabel 2.

Tahap selanjutnya adalah melakukan analisis aktivitas berupa Activity Relationship Chart (ARC) seperti pada Gambar 4 yang merupakan dasar dalam pembuatan alternatif tata letak dengan dengan memperhatikan modifikasi dan batasan praktis. Untuk membuat rancangan tata letak dapat dibuat suatu block layout yang merupakan diagram blok dengan skala tertentu dimana luas tata letak

Tabel 1. Panjang Lintasan Material Handling Layout Awal (m)

\begin{tabular}{|c|c|c|c|c|c|c|c|c|c|c|}
\hline $\begin{array}{c}\text { Ke } \\
\text { Dari }\end{array}$ & 1 & 2 & 3 & 4 & 5 & 6 & 7 & 8 & Total & Keterangan \\
\hline 1 & & 19,8 & & & & & & & 19,8 & Pintu masuk \\
\hline 2 & & & 3,8 & & & & & & 3,8 & Tempat bahan baku \\
\hline 3 & & & & & 4,5 & & & & 4,5 & Stasiun Perendaman dan pengilingan \\
\hline 4 & & & & & 14 & & & & 14 & Area kayu bakar \\
\hline 5 & & & & & & 0,6 & & & 0,6 & Stasiun perebusan dan pembibitan \\
\hline 6 & & & & & & & 6 & & 6 & Stasiun pengepresan dan pemotongan \\
\hline 7 & & & & & & & & 7 & 7 & Gudang bahan jadi 1 \\
\hline 8 & & & & & & & & & 0 & Gudang Bahan Jadi 2 \\
\hline Total P & & $\mathrm{n} M a$ & $\mathrm{Hal}$ & & & & & & 55,7 & \\
\hline
\end{tabular}


Tabel 2. Rekapitulasi Kebutuhan Luas Area Keseluruhan

\begin{tabular}{|c|c|c|c|}
\hline \multicolumn{4}{|c|}{ LEMBAR KEBUTUHAN LUAS AREA KESELURUHAN } \\
\hline $\begin{array}{c}\text { Departemen/ } \\
\text { Stasiun Kerja }\end{array}$ & $\begin{array}{c}\text { Luas } \\
\left(\mathrm{m}^{2}\right)\end{array}$ & $\begin{array}{l}\text { Jumlah } \\
\text { Fasilitas }\end{array}$ & $\begin{array}{l}\text { Total Luas } \\
\text { Lantai }\left(\mathrm{m}^{2}\right)\end{array}$ \\
\hline Gudang Bahan Baku & 15 & 1 & 15 \\
\hline Gudang Bahan Jadi & 10,65 & 1 & 10,65 \\
\hline Area Kayu Bakar & 21 & 1 & 21 \\
\hline Tempat sisa ampas tahu & 3 & 1 & 3 \\
\hline Kolam Limbah & 39 & 1 & 39 \\
\hline $\begin{array}{l}\text { Stasiun Perendaman dan } \\
\text { Penggilingan }\end{array}$ & 11,1 & 1 & 11,1 \\
\hline $\begin{array}{l}\text { Stasiun Perebusan dan } \\
\text { Pembibitan }\end{array}$ & 16,52 & 1 & 16,52 \\
\hline $\begin{array}{l}\text { Stasiun Pengepresan dan } \\
\text { Pemotongan }\end{array}$ & 7,5 & 1 & 7,5 \\
\hline Ruang istirahat & 14 & 1 & 14 \\
\hline Toilet & 9 & 1 & 9 \\
\hline Parkir & 24 & & 24 \\
\hline Total Luas Area Pelaya & & & 170,77 \\
\hline
\end{tabular}

keseluruhan dibuat berdasarkan data pada Tabel 2 . Sebelum pembuatan detail layout, dibuatlah Area Alocation Diagram (AAD), dimana diusulkan untuk alternatif pembuatan layout, gudang bahan jadi 2 pada layout awal diubah menjadi tempat parkir, karena keterbatasan dari lahan parkir yang ada di pabrik ini.

\section{Perancangan Metode 5S}

Tahap ini merupakan tahap awal dari penerapan metode 5S. Pada tahap ini dilakukan sebuah perancangan penerapan apa saja yang akan dilakukan nantinya. Selain itu pada tahap ini juga dilakukan penentuan lokasi yang akan diterapkan metode 5S ini. Sebagai contoh pada proses pemilahan, pertama kita harus melakukan identifikasi ruang lingkup dan target yang akan diterapkan proses pemilahan pada penelitian ini. Area yang akan dilakukan proses

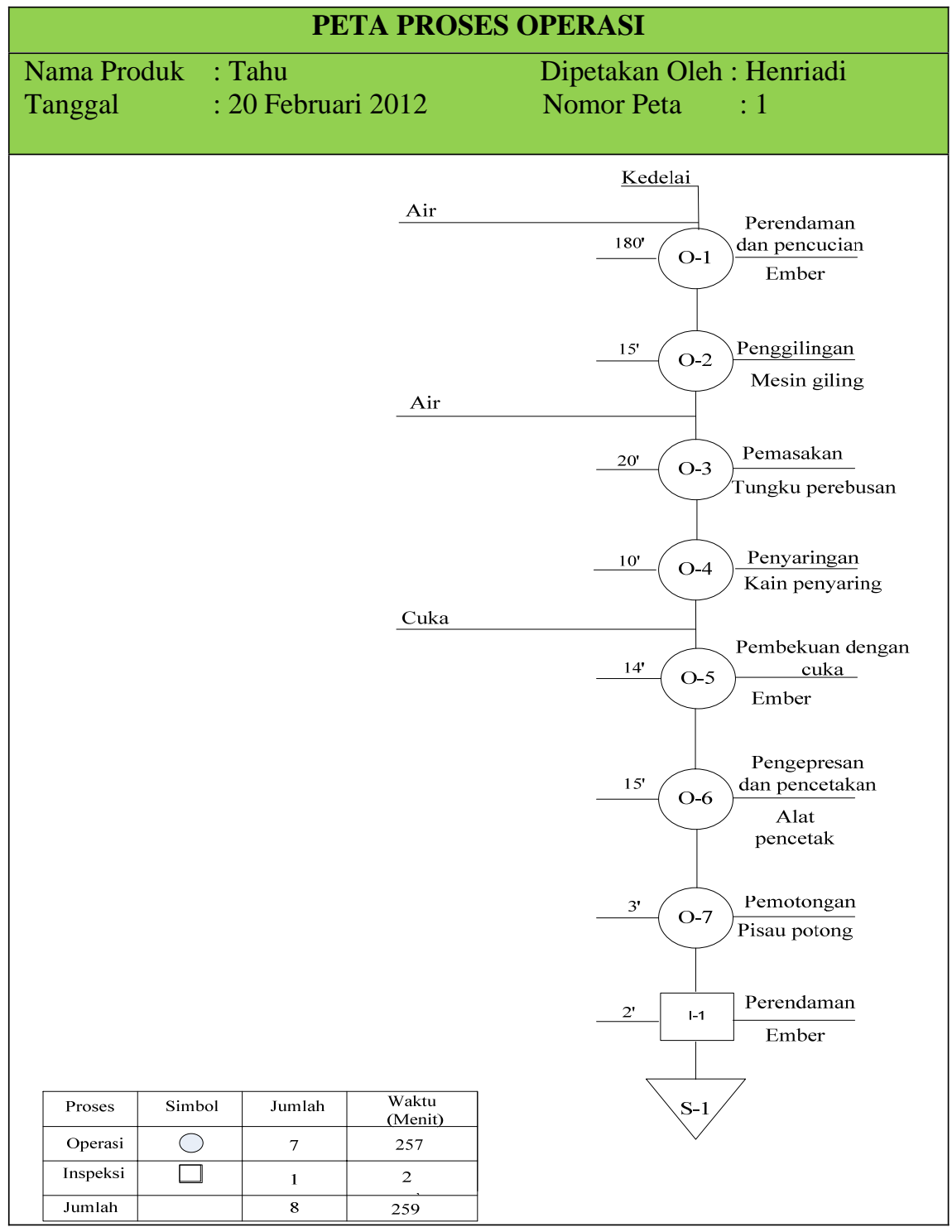

Gambar 3. Peta Proses Operasi Pembuatan Tahu 


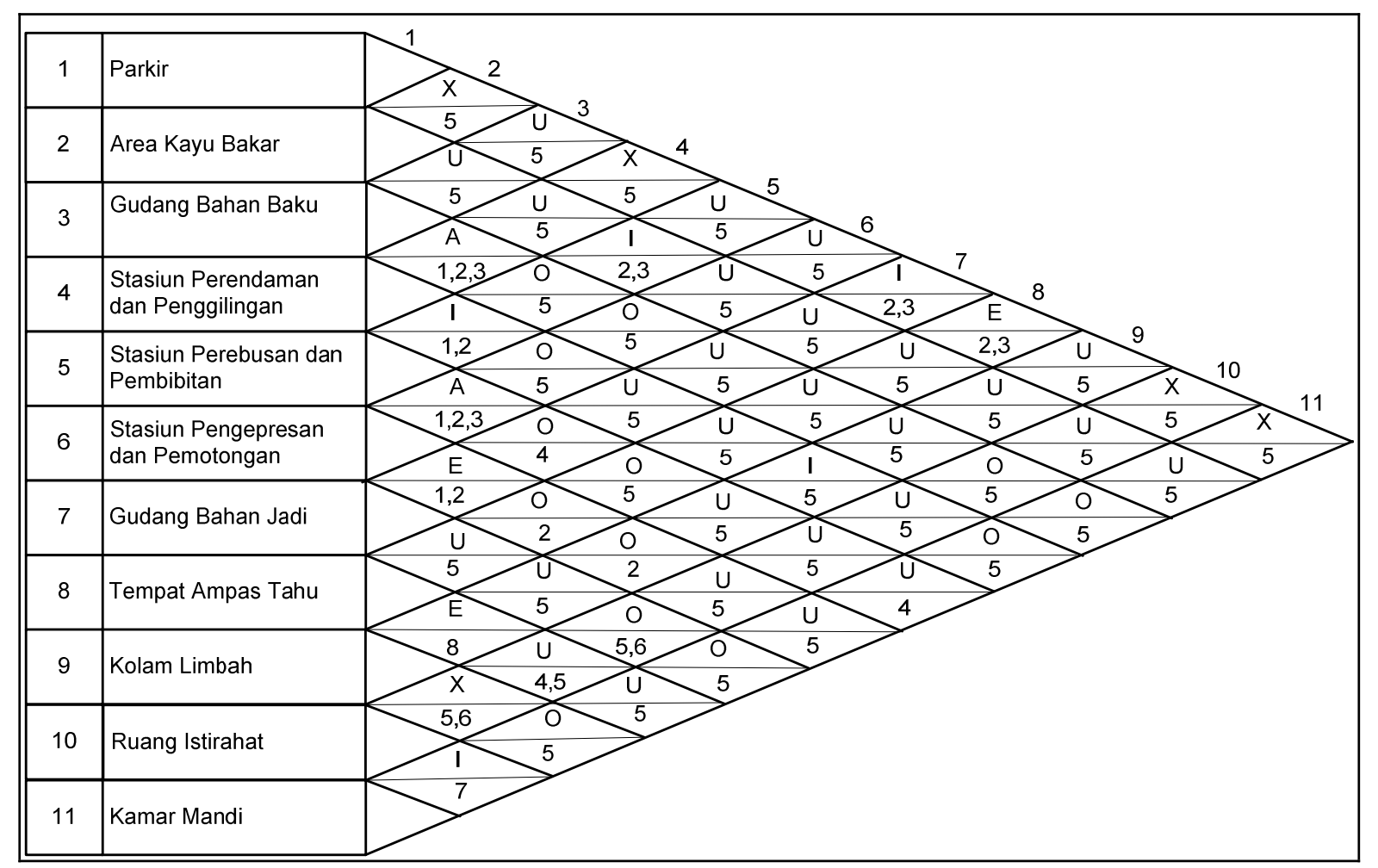

Gambar 4. Activity Relationship Chart (ARC)

pemilahan adalah pada area gudang bahan jadi dan area stasiun perendaman dan penggilingan. Setelah itu dilakukan identifikasi apa saja yang perlu dipilah atau dipisahkan pada ruang lingkup yang telah dipilih yaitu ember kosong dipisahkan dari ember yang berisi kedelai maupun yang berisi tahu yang sudah jadi.

Seiton, untuk tahap awal dilakukan analisis, kemudian menentukan tempat penataan yang tepat, menentukan cara penyimpanan peralatan yang baik, kemudian dilakukan kegiatan untuk menaati aturan penyimpanan yang telah dibuat.

Seiso, tahap awal yang dilakukan adalah melakukan identifikasi dan menentukan sasaran. Pada penelitian ini dapat diidentifikasi bahwa banyak sampah yang berserakan pada lantai produksi dan kurangnya pembersihan peralatan setelah selesai bekerja. Setelah masalah dan sasaran dapat diketahui maka barulah dilakukan proses pembersihan baik itu pembersihan lantai produksi maupun peralatan yang digunakan. Apabila sudah dibersihkan maka akan dilakukan identifikasi sumber penyebab kotoran dan mencari solusi pencegahan agar bisa mengurangi lantai dan peralatan tidak kotor lagi.

Seiketsu, perancangan yang akan dilakukan pada tahap ini adalah pemberian label dan batas area kerja yang bertujuan agar para pekerja mengetahui tempat dan batas penempatan peralatan maupun area kerja, sehingga nantinya pekerja bisa terbiasa dengan penerapan metode $5 \mathrm{~S}$ yang telah dirancang.
Shitsuke, perancangan yang dilakukan pada tahap ini adalah tertuju pada pimpinan perusahaan, untuk selalu mengontrol pekerjanya agar terbiasa dengan penerapan metode $5 \mathrm{~S}$ ini dengan memberikan penyuluhan tiap minggu maupun melakukan pengontrolan secara langsung ke lapangan.

\section{Sosialisasi Penerapan Metode 5S}

Setelah tahap perancangan selesai dilakukan, maka barulah dilakukan tahap sosialisasi. Pada tahap ini dilakukan sosialisasi dengan memberikan penjelasan tentang $5 \mathrm{~S}$ dan memberikan pengarahan bagaimana cara untuk mengaplikasikan metode ini pada lingkungan kerja, selain itu juga dijelaskan tentang rancangan $5 \mathrm{~S}$ yang telah dibuat. Hal ini bertujuan agar para pekerja bisa mengerti dan memahami tentang $5 \mathrm{~S}$, sehingga penerapan $5 \mathrm{~S}$ bisa lebih mudah untuk diterapkan.

\section{Penerapan Metode 5S}

Pada tahap ini barulah metode 5S diterapkan pada lingkungan kerja pembuatan tahu UD. Dhika Putra.

\section{Seiri}

Metode seiri banyak diterapkan pada stasiun perendaman dan penggilingan serta pada area gudang bahan jadi, karena pada kedua departemen 
ini terlihat jelas banyaknya ember yang berserakan di lantai. Ember-ember ini terdiri dari ember yang berisi kedelai maupun yang berisi tahu yang sudah jadi dan ember yang kosong, sementara ember yang kosong ini tidak diperlukan dalam stasiun perendaman dan penggilingan serta pada gudang bahan jadi. Emberember yang kosong ini membuat lantai menjadi penuh sehingga tidak ada ruangan untuk pekerja untuk melakukan proses perendaman dan penggilingan. Melihat keadaan tersebut maka diterapkan seiri yaitu dengan melakukan pemilahan terhadap ember-ember yang tidak diperlukan atau ember yang kosong dan menyimpannya pada area diluar area gudang bahan jadi serta pada stasiun perendaman dan penggilingan. Dari hasil pemilahan ini maka diperoleh keadaan lantai terlihat lebih memiliki ruangan sehingga pekerja lebih leluasa untuk melakukan pekerjaannya terutama pada proses material handling pemindahan kedelai yang sudah digiling menuju stasiun perebusan sehingga seringkali jarak pemindahan menjadi jauh karena pekerja harus melewati area yang kosong yang tidak terhalang oleh ember-ember yang berserakan pada stasiun perendaman dan penggilingan.

\section{Seiton}

Seiton merupakan S yang kedua dari metode 5S. Pada tahap ini merupakan kelanjutan dari seiri, dimana dari hasil pemilahan yang telah dilakukan akan dilanjutkan dengan proses penataan peralatan yang telah dipilah tersebut. Misalnya ember-ember yang ada pada stasiun perendaman dan penggilingan ditata pada area ember kosong tepatnya disamping gudang bahan jadi. Begitu juga dengan ember kosong yang bercampur pada gudang bahan jadi juga disusun pada area ember kosong. Selain penataan posisi ember, pada pabrik ini juga dilakukan penataan terhadap kain blacu yaitu kain untuk proses penyaringan ampas tahu dan juga penataan terhadap posisi alat press. Kain blacu digantung pada satu tempat saja sehingga pekerja lebih mudah untuk mencari dan mengambilnya apabila dibutuhkan. Sedangkan untuk alat press disusun pada stasiun pengepresan dan pemotongan, alat press tersebut disusun diatas meja press dan potong sehingga pekerja lebih mudah mengambil dan menggunakannya.

\section{Seiso}

Pada tahap ini hal yang dilakukan adalah proses pembersihan. Adapun pembersihan yang dilakukan adalah pembersihan terhadap lantai produksi dan peralatan yang digunakan untuk proses produksi pembuatan tahu yaitu mesin giling dan kuali perebusan dan pembibitan. Lantai pabrik dibersihkan dari sampah-sampah baik itu sampah plastik, kedelai yang terjatuh dan cairan sisa pencucian dan penggilingan kedelai. Pembersihan lantai produksi ini bertujuan demi keamanan dan kenyaman pekerja pada saat melakukan pekerjaannya, karena jika lantai licin dan kotor bisa membuat pekerja tergelincir dan jatuh. Sedangkan untuk pembersihan peralatan kerja dilakukan dengan tujuan perawatan terhadap peralatan tersebut.

\section{Seiketsu}

Pada tahap ini lebih mengarah pada proses pemantapan terhadap metode $5 \mathrm{~S}$ yang telah diterapkan. Pada tahap ini dilakukan suatu upaya bagaimana penerapan yang telah dilakukan tetap berlangsung terus menerus bukan untuk sementara saja dengan cara pembuatan label area kerja seperti area bahan baku, area bahan jadi, tempat ember kosong dan tempat kain blacu. Selain itu juga dilakukan pembuatan garis batas area kerja yang bertujuan agar penyusunan peralatan kerja lebih tertata dengan baik. Dengan adanya pembuatan labeling dan garis batas area kerja bisa membuat karyawan mengetahui dimana penempatan peralatan yang digunakan dan mengetahui batas areanya, sehingga penerapan ini bisa berlangsung terus menerus.

\section{Shitsuke}

Tahap ini merupakan bagian terakhir dari metode 5S. Pada bagian ini lebih memfokuskan bagaimana cara untuk membiasakan diri terhadap penerapan metode ini. untuk itu diperlukan kesadaran dari para pekerja untuk memiliki pola kerja yang sesuai metode 5S demi kenyamanan dan keamaan dalam bekerja. Mengingat sifat manusia yang berbeda-beda maka perlu seseorang yang bisa mengontrolnya. Dalam hal ini peran pimpinan dibutuhkan untuk peduli dan mampu mengontrol pekerja agar selalu menjaga lingkungan kerja berdasarkan metode $5 \mathrm{~S}$ yang telah diterapkan.

\section{Evaluasi Penerapan Metode 5S}

Tahap evaluasi ini adalah tahap untuk menilai apa saja perancangan metode $5 \mathrm{~S}$ yang bisa diterapkan. Dari hasil penerapan yang dilakukan maka dapat dievaluasi perancangan yang mampu diterapkan dapat dilihat pada Tabel 3. Tahap evaluasi yang dilakukan selama lebih kurang 6 hari. Pada hari pertama semua rancangan masih diterapkan pada pabrik tahu UD. Dhika Putra dengan baik walaupun masih belum sempurna. Namun pada hari selanjutnya terjadi beberapa metode $5 \mathrm{~S}$ yang tidak dilakukan misalnya pemisahan antara ember kosong dengan ember yang berisi dengan kedelai serta kurang pedulinya pekerja untuk meletakkan kain blacu pada area yang telah ditentukan. 
Tabel 3. Hasil Evaluasi Perancangan yang Mampu untuk Diterapkan

\begin{tabular}{|c|c|c|}
\hline Metode 5S & Pelaksanaan & Stasiun/Departemen \\
\hline \multirow[t]{2}{*}{ Seiri (Pemilahan) } & Pemisahan antara ember yang berisi kedelai dengan ember kosong & Perendaman dan Penggilingan \\
\hline & Pemisahan antara ember yang berisi tahu dengan ember kosong & Gudang bahan jadi \\
\hline \multirow[t]{3}{*}{ Seiton (Penataan) } & $\begin{array}{l}\text { Ember yang kosong yang telah dipisahkan dari ember-ember yang } \\
\text { berisi yang berada pada gudang bahan jadi dan stasiun perendaman } \\
\text { dan penggilingan di letakkan pada area penempatan ember kosong }\end{array}$ & Area ember kosong \\
\hline & $\begin{array}{l}\text { Kain blacu digantung pada satu tempat saja yaitu pada area tempat } \\
\text { kain blacu }\end{array}$ & Area kain blacu \\
\hline & $\begin{array}{l}\text { Peralatan alat untuk pengepresan disusun pada meja pengepresan } \\
\text { dan pemotongan }\end{array}$ & Pengepresan dan Pemotongan \\
\hline \multirow{2}{*}{$\begin{array}{l}\text { Seiso } \\
\text { (Pembersihan) }\end{array}$} & Pembersihan Lantai Produksi & Lantai produksi \\
\hline & Pembersihan peralatan kerja & Semua stasiun \\
\hline \multirow[t]{3}{*}{$\begin{array}{l}\text { Seiketsu } \\
\text { (Pemantapan) }\end{array}$} & Pembuatan garis batas-batas area kerja & $\begin{array}{l}\text { Perendaman dan penggilingan, gudang } \\
\text { bahan baku, emeber kosong }\end{array}$ \\
\hline & Pembuatan jadwal piket & - \\
\hline & Pembuatan label nama area & $\begin{array}{l}\text { Area gudang bahan baku dan bahan jadi, } \\
\text { area ember kosong dan stasiun perendaman } \\
\text { dan penggilingan }\end{array}$ \\
\hline \multirow{2}{*}{$\begin{array}{l}\text { Shitsuke } \\
\text { (Pembiasaan) }\end{array}$} & Melakukan pengontrolan tiap harinya & Semua Stasiun \\
\hline & Upaya Pembiasan diri & Semua Stasiun \\
\hline
\end{tabular}

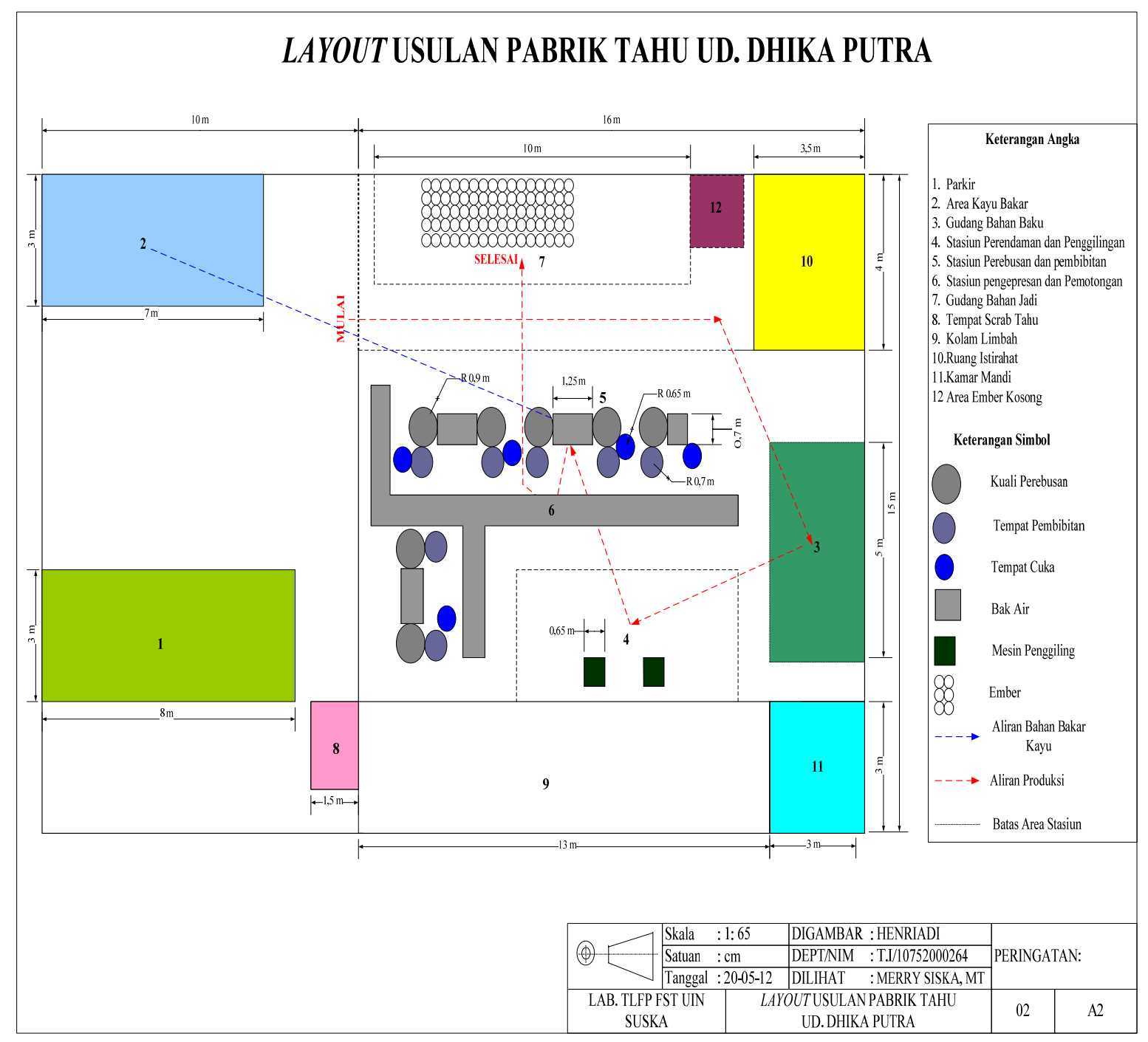

Gambar 5. Layout Usulan 


\section{Layout Akhir}

Pembuatan layout akhir ini dibuat berdasarkan layout usulan yang terpilih yang memiliki panjang lintasan material handling yang paling pendek yang kemudian dikombinasikan dengan rancangan penerapan metode 5S. Adanya penambahan area untuk penataan ember kosong dan adanya ruangan yang memungkinkan proses material handling kedelai yang digiling dari stasiun perendaman dan penggilingan menuju stasiun perebusan menjadi lebih mudah dilakukan dan juga bisa memperpendek jarak lintasan material handlingnya. Adapun gambar layout akhir dapat dilihat pada Gambar 5.

\section{SIMPULAN}

Rancangan ulang tata letak dan fasilitas pabrik pembuatan tahu UD. Dhika Putra yang terpilih adalah layout alternatif 1 yang memiliki panjang lintasan material handling $45 \mathrm{~m}$, hasil ini lebih efisien $19.21 \%$ jika dibandingkan dengan panjang aliran material handling layout awal yaitu $55,7 \mathrm{~m}$ dan layout usulan alternatif 2 sepanjang $49 \mathrm{~m}$. Penelitian ini berhasil menerapkan metode 5S di UD. Dhika Putra yang dapat dilihat pada Tabel 3, misalnya pemilahan ember-ember kosong yang berada pada area gudang bahan jadi maupun pada stasiun perendamaan dan penggilingan, diterapkannya penataan peralatan pada area yang telah ditentukan, penerapan kegiatan pembersihan lantai produksi dan peralatan, serta pemberian label dan batas peralatan dan area kerja. Melalui penerapan metode 5S ini kondisi fisik lingkungan kerja di pabrik tahu lebih tertata rapi dan berpengaruh pada kenyamanan pekerja.

\section{DAFTAR PUSTAKA}

Apple J. M., 1990. Tata Letak Pabrik dan Pemindahan Bahan. Edisi ketiga. ITB. Bandung.

Hadiguna, R. A., dan Setiawan, H., 2008. Tata Letak Pabrik. Andi. Yogyakarta.

Listiani T., 2010. Penerapan Konsep 5S alam Upaya Menciptakan Lingkungan Kerja yang Ergonomis di STIA LAN Bandung. Jurnal Ilmu Administrasi, VII (3), Bandung.

Osada, T., 2004. Sikap Kerja 5S. Cetakan Kelima. PPM. Jakarta.

Purnomo, H., 2004. Perencanaan dan Perancangan Fasilitas. Cetakan Pertama. Graha Ilmu. Yogyakarta.

Wignjosoebroto, S., 2009. Tata Letak Pabrik dan Pemindahan Bahan. Edisi ketiga. Guna Widya. Surabaya. 